\title{
洋上風力発電基礎の設計手法について \\ FOUNDATION DESIGN METHODS FOR OFFSHORE WIND ENERGY CONVERTION SYSTEMS
}

\author{
勝海務 $1 \cdot$ 井上博士 $2 \cdot$ 岡島伸行 $3 \cdot$ 小林明夫 $4 \cdot$ 山川真 5 \\ Tsutomu KATSUUMI,Hiroshi INOUE,Nobuyuki OKAJIMA,Akio KOBAYASHI \\ and Makoto YAMAKAWA
}

\begin{abstract}
1正会員 工修 （財）沿岸開発技術研究センター研究主幹（テ102-0092千代田区隼町3-16）
2正会員（財）治岸開発技術研究センター調査部主任研究員（テ102-0092千代田区隼町3-16）

3正会員（財）沿岸開発技術研究センター調査部主任研究員（广102-0092千代田区隼町3-16）

4 (財) 沿岸開発技術研究センター調査部主任研究員（テ102-0092千代田区隼町3-16）

5 (財) 治岸開発技術研究センター波浪情報部研究員（テ102-0092千代田区隼町3-16）
\end{abstract}

\begin{abstract}
It is important to promote the introduction of new energies that impose low loads on the environment. Wind power is viewed as a promising new energy source that is pure, clean, and inexhaustible. In the coastal areas, wind is not disturbed by structures and relatively stakes. These areas therefore, are suitable for constructing wind energy conversion systems. This report describes the design method of the foundation and the execution methodologies for offshore wind energy conversion systems.
\end{abstract}

Key Words :wind,energy, wind power, offshore,port,havbor,structure,coastal deveropment,foundation

\section{1.はじめに}

20 世紀から 21 世紀へ, 引き継がれた大きな課題 として「エネルギー問題」と「地球環境問題」があ

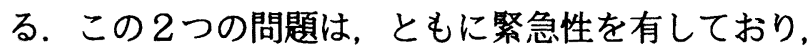

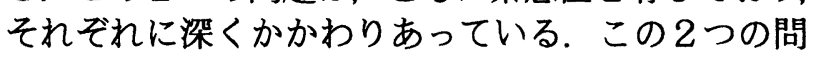
題を同時に解決に導く対策は, 非化石エネルギー導 入の推進であり，国際的関心のもと，化石燃料から 自然エネルギー、リサイクル・エネルギーなど新し いエネルギー源への転換について様々な取り組みが なされている.この様な取り組みのなか, 太古の昔 からさまざまに利用されてきた無尽蔵のエネルギー

「風」を利用した風力発電が注目され，さらにこの 発電方法が二酸化炭素を排出しないクリーンなもの であることにより，尚一層の期待が注がれている.

日本においても，1990 年代に入り，電力会社を 中心に試験・実証用の大型風力発電機の設置が盛ん になり, 1990 年代後半からは発電事業としての設 備の設置も増えてきている。 しかし，これまでの風 力発電設備は陸上に限られたものであったため, そ の設置場所の条件としては, 安定的な風に恵まれて いることはもちろんのこと, 設置場所への搬入路や
送電線の確保が必要であり，地形の複雑な日本に とっては潜在的な制約が多くコスト高の要因になっ ていた．今後わが国が風力エネルギーを活用してい くためには，世界有数の海岸線の長さを有する海洋 国家という地理的条件を生かし，陸上に比べて障害 物が少なく，安定的で良好な風が得られる港湾・沿 岸域での利用を可能とすることが，我が国での新し いエネルギー源の転換の促進につながると考えられ る. この様な背景のもと, 財団法人 沿岸開発技術 研究センターでは, 平成 11 年度より民間企業との 共同研究により港湾・沿岸域における風力発電シス テムに係わる工法の技術開発とその普及を目的とし て研究を進めており，その研究の成果を 2000 年 11 月に「洋上風力発電基礎工法の技術（設計・施工） マニュアル（案)」（以下，マニュアル案と称す）と してまとめるとともに, 港湾沿岸域における風力発 電技術検討委員会 (委員長: 清宮理 早稲田大学教 授）を設置さらに詳細な研究を進めている.

本稿は，マニュアル案の概要を紹介するとともに (財) 沿岸開発技術研究センターでの研究内容につ いて報告するものである. 


\section{2. 洋上風力発電の有効性}

\section{（1）何故, 洋上風力発電なのか}

\section{a）洋上は風が強い}

一般に洋上における風速は陸上と比べて強く，沿 岸から離れた海域においては，20\%程度の風速の増 加がみこまれており, 陸上部の地形によっては近接 する陸上部にくらべ沿岸部の風速が 40\%から $80 \%$ 程度まで大きい実測例もある。.また海上では障害物 がないため安定的で良好な風が得られる.

b）大型風車の設置及び運搬が可能

風車は大型化するほど経済的であるため，年々大 型化している．現在国内最大規模である北海道苫前 町に設置されている機種では，ブレード（回転羽） 1 枚の長さ約 $33 \mathrm{~m}$, タワー（風車の支柱部分）高 $60 \mathrm{~m}$ ，タワー最大径約 $4 \mathrm{~m}$ となっている. このクラ スになると，陸上での設置及び運搬が可能な場所は 限定されるが，洋上または沿岸部では海上及び港を 利用し，大型作業船による作業が可能なため, この 様な問題は少ない。

c）環境に関する問題が少ない

風力発電機は, ブレードが回転する際, 多少の騒音 の発生がある．また，タワー，ナセルが金属製であ るため, 電波障害を発生する危険性もある. しかし 洋上においては，このようなことが問題となること は陸上に比べて少ない.

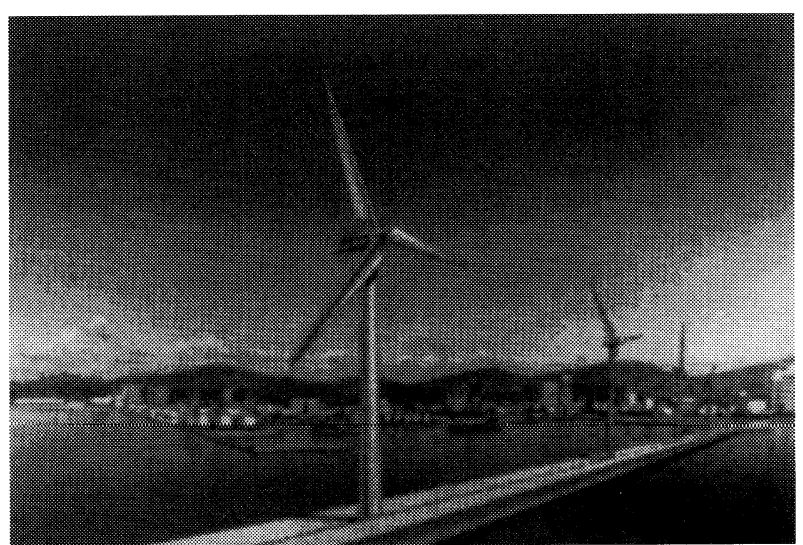

図ー1 防波堤上に風車を設置したイメージ図

\section{（2）洋上風力発電の推進にあたっての課題}

洋上風力発電推進のための課題としては, (1)洋上 風力発電の基礎の建設費が高価，(2)送電費用が高価， (3)漁業との調整が必要, (4)景観・生物への影響等の 環境上の問題等がある. さらに基本的な問題として は，洋上風力発電施設設置に関する，設計・施工手 法が確立されていない点が挙げられる.

\section{3. 基碟の構造種別}

洋上風車基礎は，孤立した基礎と防波堤のように 他に機能を持つ構造物を基礎に利用する場合とに分 類できる，構造形式としては，図一2に示すように，
重力式，杭式，浮体式等が挙げられる，構造形式の 選定にあたっては, 安定検討に加えて, 経済性, 施 工性等を十分考慮する必要がある.

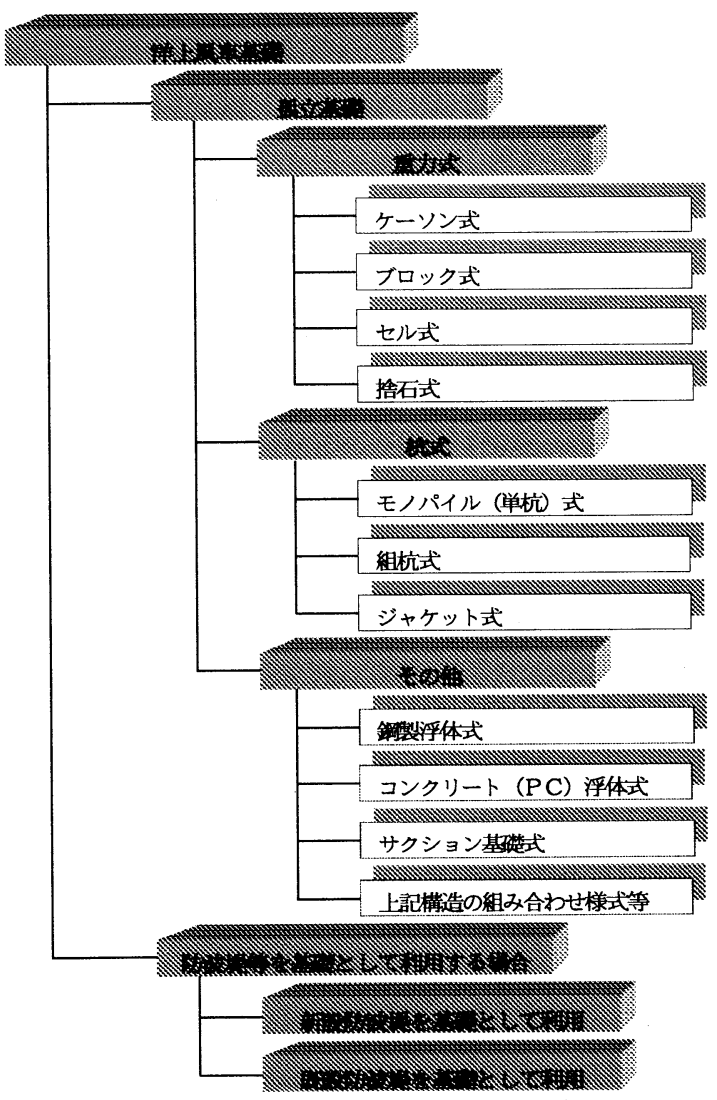

図一２洋上風車基礎構造種別

図ー3〜 5 に主な基礎構造形式の例を示す.

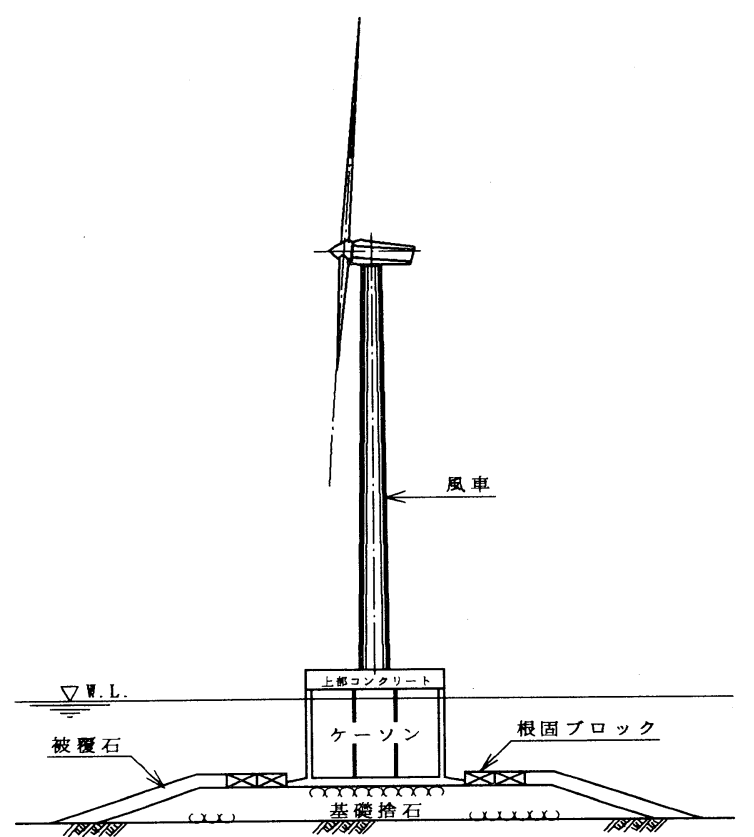

図ー3 重力（ケーソン）式基礎の例 


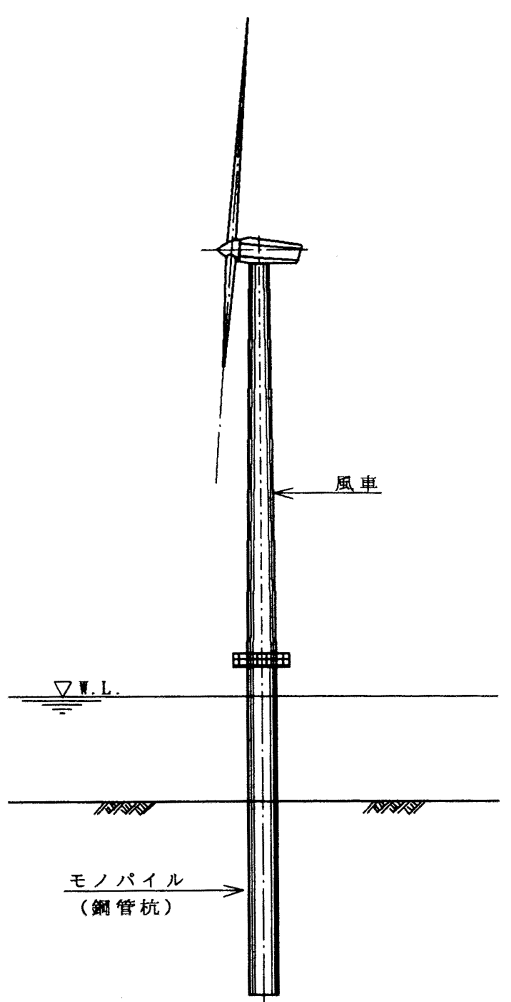

図-4 杭（モノパイル）式基礎の例

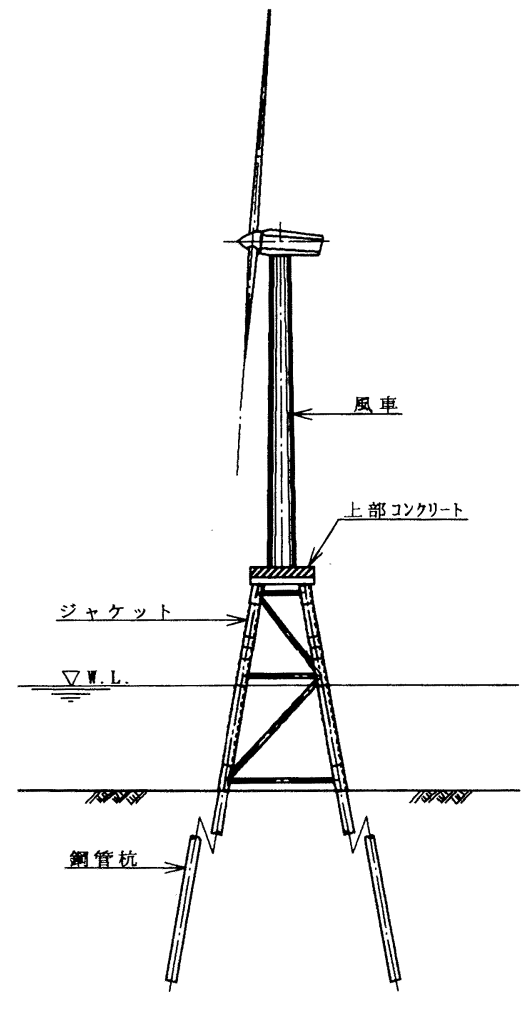

図一 5 ジャケット式基礎の例

\section{4. 設計手法}

（1）新設する防波堤を基礎として利用した場合 新設防波堤を基礎として風車を設置する場合の標
準的な設計手法を以下に示す.

a）設計の手順

新設防波堤を基礎として風車を設置する場合の標 準的な設計は，次のフローに従って実施する.

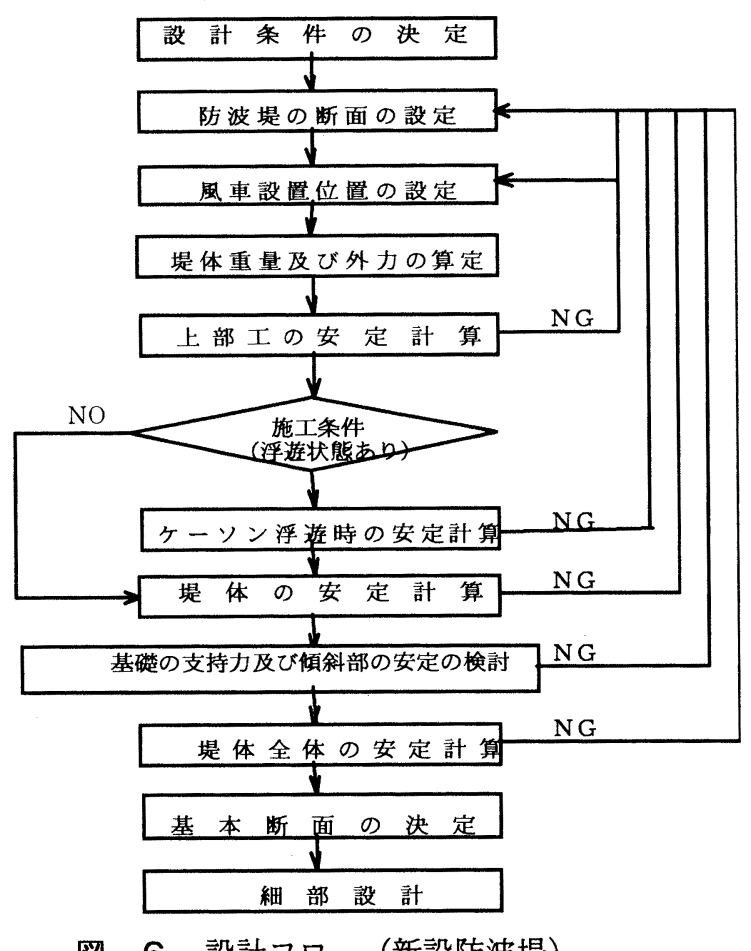

\section{b）設計条件の決定}

新設防波堤を基礎とする設計条件としては，次の 項目を考慮する.

自然条件 潮位, 風, 波浪, 土質条件, 地震力等 利用条件 本体工 (上部工), 計画天端高, 計画 水深等

施工条件 ケーソン製作・据付条件等

風車条件 風車諸元

その他摩擦係数, 単位体積重量, 準拠基準等

c）防波堤の断面の設定

防波堤上に風車を設置する場合, 風車設置部の ケーソンの形状（天端高, 堤体幅, 堤体長さ等) は, 一般部ヶーソンの形状を考慮して設定することが望 ましい，ただし，堤体安定計算結果等により風車設 置部ケーソンの形状を一般部と異なるものにする必 要がある場合には, ケーソン幅の変更, フーチング 形状の変更などの方法により断面を適切に設定する. d）風車設置位置の設定

風車の設置位置は, 防波堤の利用条件, 風車設置 に関わる施工性，及び経済性等を勘案して決定する。 e) 堤体重量及び外力の算定

ケーソンの安定計算に当たっては，以下の外力を 考虑する.

自重（ケーソン, 風車)

地震力（ケーソン, 風車)

波力及び浮力（ケーソン, 風車）

風圧力 (風車)

検討は基本的には暴風時と地震時について行う. 
暴風時は, 港外方向から港内方向に波力及び風圧 力を作用させるが, 地震時は, 風車設置位置により 支配的な方向に地震力, 風圧力を作用させて検討を 行う.

風車設置部ケーソンに作用する外力の概念図を図 -7 に示す. なお, 外力は通常, 単位奥行き当たり で算定する. 風車に作用する外力についても同様に, ケーソン奥行き長さで除して算定する.

\section{f）上部工の安定計算}

風車設置部ケーソンの上部コンクリートと風車を 一体として考え, 上部工の安定計算を行う. 安定計 算は，滑り出し，転倒についてそれぞれ行う.

\section{g）ケーソン浮遊時の安定計算}

施工条件により，ケーソン浮遊時の安定計算を行 う必要がある場合には，港湾の施設の技術上の基準 に従う。

\section{h）堤体の安定計算}

堤体の安定計算は，ケーソンと風車を一体として 考え, 全体系についての滑り出しと転倒の検討を行 う. 検討は暴風時と地震時について行うことを基本 とする.

\section{j）基碟の支持力及び傾斜部の安定の検討}

偏心傾斜荷重に対するすべりの検討は, 港湾の施 設の技術上の基準に従って算定する.

\section{k）堤体全体の安定計算}

堤体全体の安定計算は, 円弧すべり計算で行う.

以上が新設する防波堤上に風車を設置する場合の 手順である. マニュアル案には, 孤立基礎の例とし て, 重力 (ケーソン) 式, モノパイル式, ジャケッ ト式についても設計手順を示している.

\section{（2）既設の防波堤を基礎として考えた場合}

既設の防波堤の上に風車を設置する場合の設計手 法を以下に示す。

a）既設防波堤を基礎として風車を設置する場合 設計は，図一8のフローに従って実施する.

設計の手順としては, 通常の防波堤とほぼ同様で ある.

b）既設ヶーソン

既設ヶーソンは風車を設置していない状態で最適 な設計がなされているため, 風車本体の鉛直力, 夕 ワーに作用する風荷重や波力による水平力, 転倒 モーメントなどの外力が増加する結果, 安定計算に おいて安全率を満たさない場合がある。このような 場合は, 既設ヶーソンに対策工を施した上で再度安 定計算等を行い, 所要の安全率を満たす必要がある. c) 細部設計

細部設計においても，底版部等の部材耐力が不足 する場合があるため注意する。

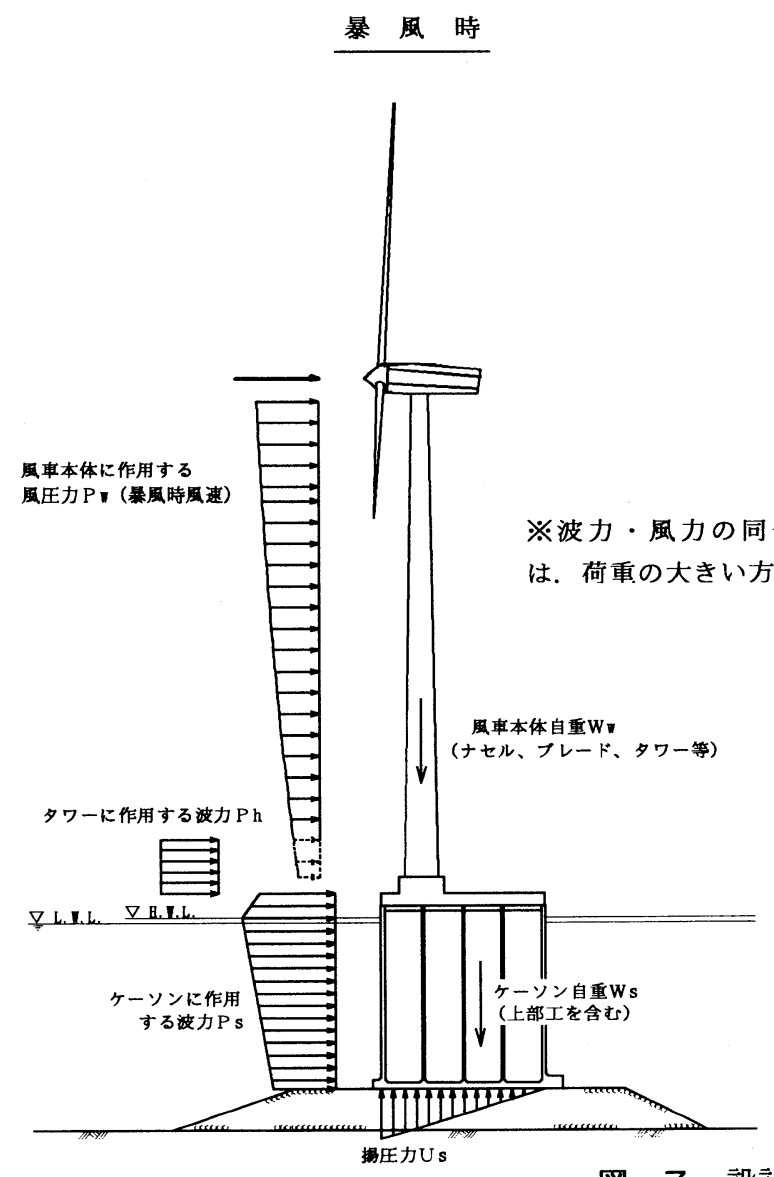

地 震 時

図-7 設計外力概念図 


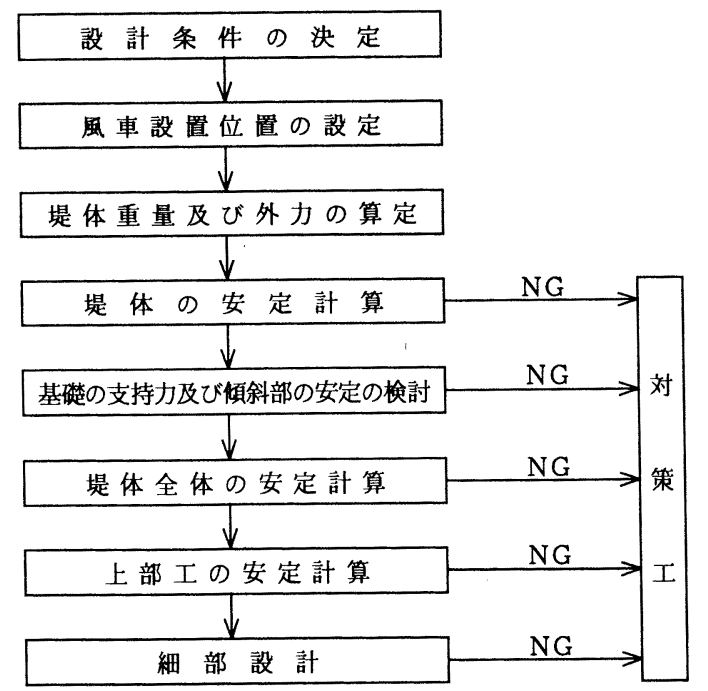

図-8 設計フロー（既設防波堤）

\section{d）対策工}

風車を設置して安定計算, 構造計算を行った結果, 所要の安全率を満たさない場合には適切な対策工を 施し, 構造上安定させる.

対策工は，現場条件等を考慮し，適切な考え方を 選定する. 以下にその例を示す.

・消波ブロックを利用し，防波堤に作用する波力 を低減する。

・防波堤ケーソンの拡幅, フーチングの設置（延 伸).

・設置する風車の規模を小さくする.

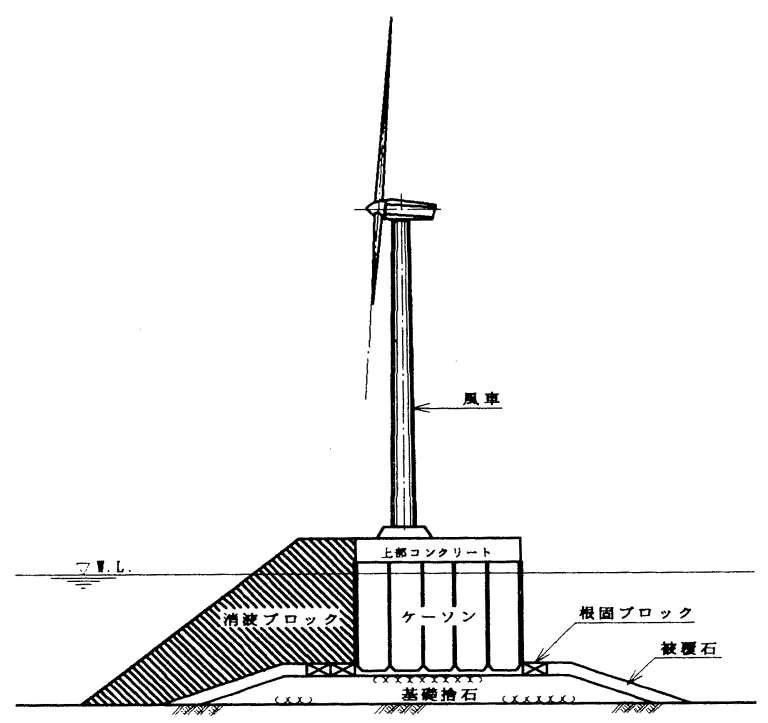

図ー9 既設亜防波堤を基礎として利用する場合（消波 ブロックにて波力の低減を図る形式）

\section{5. 今後の課題}

マニュアル案については，港湾沿岸域における風 力発電技術検討委員会において整備中であるが今後 検討すべき課題について以下に示す.

\section{（1）合理的設計手法の確立}

風車本体の耐用年数は 20 年としている例が多い. 基礎の設計供用期間を風車の耐用年数と合わせるか, 基礎を本体構造とした場合の設計供用期間とするか を適正に判断する必要がある。設計に用いる外力に ついては，再現期間と構造物の耐用年数に基づいた 遭遇確率から求めることが望ましい，しかし，遭遇 確率をどのように設定するかは，構造物の機能，重 要度, ライフサイクルコストに左右されるものであ り，どのような信頼度を持つ構造物を造るかを明確 にする必要がある.

\section{（2）風荷重}

風車基礎設計における風荷重の計算手法について は国内基準がなく，陸上の風車基礎設計においても， メーカ一，施工業者により設計方法が統一されてい ない，マニュアル案は，平成 12 年 6 月に改正され た建築基準法をべースとしているが課題が多い.

\section{a）風車運転時の風荷重計算手法の明確化}

土木建築関係基準の風荷重計算は, 対象物体が静 止していることを前提としており，風車運転時のよ うな, ブレードが回転している状態での外力の算定 を想定していない. 今回はメ一カ一の提示値を用い ることを原則とするとしているが，海外メーカーの 場合は計算根拠を明示しない場合があり，メ一カー の提示值の取り扱いを含め計算手法を明確化する必 要がある.

b)建築基準法を適用する場合のナセル, ブレードの 形状係数の設定（風車停止時）

マニュアル案では，板状構造物の值を用いている が，本来は風洞実験に基づいた值を用いるべきであ る.

\section{（3）地震時}

一般に基礎の設計では，地震時に風力，波力を考 慮する事はしない. しかしながら、マニュアル案で は，陸上での多くの設計例にならい地震時に定格風 速 $(16 \mathrm{~m} / \mathrm{s}$ 程度) が風車に作用することを考慮し ている.

\section{（4）波圧}

デルフト大学が中心になって行った E Uの洋上風 力発電に関する最終報告書 ${ }^{1)}$ のなかでは, 最大外力 を「最大波圧十最大風圧」としていない。最大波圧 と最大風速の同時性は極めて少なく，作用時間も瞬 間的なものになる. そのため, 合理的な設計のため には設計荷重の組み合わせ時における荷重係数の導 入等を考える必要がある. 
（5）コストダウンの考虑

洋上風車基礎が陸上基礎よりも高額になることを 考え，コストダウンを考虑した最適構造（例えば没 水型ケーソン) の提案が必要となる. また開発中の 新技術であるサクション基礎等は風車の基礎構造と して有望であると考えられる。 なお，一般的な構造 形式（ケーソン式，モノパイル式，ジャケット式） については，共同研究会において基礎建設コストの 試算を行っている. 水深 $10 \mathrm{~m}$ の条件で各構造が成

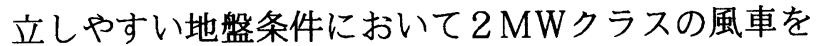
設置した場合，直接工事費として 5 千万円〜 8千万 円／基となり，陸上での施工が 2 千万円程度である ことを考えるとコストダウンが大きな課題となる.

\section{（6）工法選択フローチャートの作成}

風車基礎の各種構造については地盤条件, 荷重条 件毎に有利不利がある. 今後設計を行っていく中で 知見が得られれば，最適基礎構造の選択フローが作 成可能であり，設計業務の省力化も考えられる.

\section{（7）既設構造物への設置}

洋上での基礎が高価な事を考慮すると，既設防波 堤等に風車を設置する事ができれば有利となる。し かし，底面反力が増加することにより，地盤の支持 力不足や，底版の配筋量が不足する，という結果に なることが多い．そのような場合の既設構造物への 補強方法, 対策工法について今後の詳細な検討が求 められる。

\section{7.あとがき}

今回紹介した「洋上風力発電基礎工法の技術（設 計・施工）マニュアル（案）」については「港湾沿 岸域における風力発電技術検討委員会」での指導を 経て整備し, 洋上風力発電に関する各種特記事項に ついて追加記載したものを「洋上風力発電の技術マ ニュアル」として出版したいと考えている.このよ うなマニュアルが整備されることにより, 洋上風力 発電の実現に向けた検討が各所で具体化し, 新エネ ルギーの導入促進に貢献できると考えている.

謝辞：「洋上風力発電基礎工法の技術（設計・施 工）マニュアル（案）」は, 五洋建設株式会社, 新 日本製鐵株式会社，株式会社テトラ，大旺建設株式 会社との共同研究の成果をまとめたものである。こ れら関係者ならびに「港湾沿岸域における風力発電 技術検討委員会」において指導をいただいている, 清宮委員長及び各委員の方々に，感謝の意を表する.

\section{参考文献}

1) EU Joule III Project JOR3-CT95-0087 , OPTI-OWECS FINAL REPORT volume2 , Methods Assisting the Design of OWECS Part D, pp4-1 4-4, 1998 